\title{
İhracat ve İstihdam İlișkisi Üzerine Panel Veri Modeli Analizi: OECD Ülkeleri Örneği
}

\author{
Panel Data Model Analysis on the Relationship Between Export and \\ Employment: The Case of OECD Countries
}

\section{Hande AKSÖZ YILMAZ1 ${ }^{1}$ (1)}

\section{öz}

İhracatın istihdam üzerindeki etkisi uzun yıllardır araştırmacıların ilgi odağındadır, fakat bu alandaki literatür ortak bir paydada buluşamamış görünmektedir ve ihracat ile istihdam arasındaki ilişki hala net değildir. Bu makale, 28 OECD ülkesinin ihracatının onların istihdamları üzerindeki etkisini, birimler arasındaki farklı özelliklerin etkisini ortaya koyan, yatay kesit veri ve zaman serisi verileri birlikte kullanarak serbestlik derecesinin artmasına izin veren dolayısıyla daha etkili tahmin ediciler sunan panel veri tahmin yöntemi kullanarak incelemeyi amaçlamaktadır. Bu amaç için, makale 2001-2019 dönemini kapsayan verileri ve istihdam, ihracat, ekonomik büyüme, birim işçilik maliyetleri, işsizlik ödemesi, ticari açıklık ve finansal açıklık oranları gibi değişkenleri kullanır. Bulgulara göre 28 OECD ülkesinin ihracat büyümesi, istihdam büyümesini negatif yönde etkilemekte anlamlıdır. Ekonomik büyüme, bir önceki dönemin istihdam seviyesi, ticari açıklık ve ihracat istihdam üzerinde etkiler ortaya çıkarmaktadır. Ekonomik büyüme, önceki dönem istihdam seviyesi ve ticari açıklık, cari dönemdeki istihdamı pozitif etkilerken; ihracat, istihdam üzerinde negatif yönde etkili olmaktadır. Çalışma sonucunda elde edilen tahminler, ihracat büyümesinin istihdam büyümesine etkisinin, ihracatın istihdamı artırdığını belirten geleneksel dış ticaret teorilerinin aksine, başta ülkelerin üretim yapıları olmak üzere siyasi ve ekonomik faktörlere göre değişeceğini ima etmektedir. Hızla değişen pazar talebine uyum sağlamak ve uyumu teşvik edebilecek rekabetçi bir ortam yaratmak çok önemlidir. Politika yapıcılar ve sosyal ortaklar, eğitim ve öğretim sistemlerini endüstriye bağlama ve işgücü arzını taleple eşleştirme konusunda aktif işbirliği yoluyla oynayacakları kilit bir role sahiptir.

Anahtar Kelimeler: İhracat, İstihdam, Dış Ticaret Teorileri, İş gücü, Panel Veri Modeli

Jel Sınıflaması: F16, J23, C33

\begin{abstract}
'Dr., Kırşehir Ahi Evran Üniversitesi, İktisadi ve İdari Bilimler Fakültesi, İktisat Bölümü, KırşehirTürkiye
\end{abstract}

ORCID: H.A.Y. 0000-0002-1115-7535

\begin{abstract}
Sorumlu yazar/Corresponding author: Hande AKSÖZ YILMAZ,

Dr., Kırşehir Ahi Evran Üniversitesi, İktisadi ve İdari Bilimler Fakültesi, İktisat Bölümü, KırşehirTürkiye

E-posta/E-mail: hande.yilmaz@ahievran.edu.tr
\end{abstract}

Başvuru/Submitted: 15.02.2021

Revizyon Talebi/Revision Requested:

15.04.2021

Son Revizyon/Last Revision Received:

01.06.2021

Kabul/Accepted: 02.06 .2021

Atıf/Citation: Aksoz Yilmaz, H. (2021). İhracat ve İstihdam İlişkisi Üzerine Panel Veri Modeli Analizi: OECD Ülkeleri Örneği. Iktisat Politikası Araştırmaları Dergisi - Journal of Economic Policy Researches, 8(2), 115-139. https://doi.org/10.26650/JEPR.880876 


\begin{abstract}
For many years, researchers have focused more on the effects of exports on employment; however, the literature in this area has not found common ground, and the relationship between exports and employment is still not clear. This study investigates the impact of export on the employment of 28 OECD (The Organisation for Economic Co-operation and Development) countries using panel data estimation techniques that reveal the effect of different properties between units, allows the degree of freedom to increase, and, therefore, offers more effective estimators using cross-section data together. Thus, the study uses data spanning from 2001 to 2019 and variables such as employment, exports, economic growth, per unit labor costs, trade openness, financial openness, and unemployment payment rates. The findings reveal that the exports of $28 \mathrm{OECD}$ countries are significant and have a negative significant effect on their employment. The economic growth, employment level of the previous period, trade openness, and exports have an impact on employment. While economic growth, trade openness, and previous employment levels have a positive effect on employment in the current period, exports have a negative effect on employment. The results imply that the export may affect to employment level. depending on political and economic factors, particularly the production structures of countries, contrary to traditional foreign trade theories that state that exports increase employment. It is critical to adapt to the rapidly changing market demand and create a competitive environment that can encourage adaptation. Policymakers and social partners have a key role to play through active cooperation in connecting education and training systems to industry and matching labor supply to demand.
\end{abstract}

Keywords: Export, employment, foreign trade theories, labor force, panel data model

Jel Classification: F16, J23, C33

\title{
EXTENDED ABSTRACT
}

This study investigates the effect of export on the employment of 28 OECD countries. Thus, this study examines the effect of export on its employment within the framework of the panel data model, which presents more effective estimators. The study uses data spanning from 2001 to 2019 and variables such as employment, exports, economic growth, per unit labor costs, and unemployment payment rates. The primary motivations behind this research are twofold. First, the relationship between export and employment is presented within the framework of the panel data model. Second, the impact of exports on employment is explained taking into account other macroeconomic variables that help explain employment. Accessible data determine the scope of the study and allows the study to be analyzed on 28 OECD countries consisting of Australia, Austria, Belgium, Canada, Czech Republic, Estonia, Finland, France, Germany, Greece, Hungary, Ireland, Israel, Italy, Japan, Korea, Latvia, Luxembourg, New Zealand, Norway, Portugal, Slovenia, Spain, Sweden, Switzerland, Turkey, United Kingdom, and the United States.

In the literature, a large amount of empirical research was conducted, which examined the relationship between export and employment for different countries. These studies were analyzed for the relationships between the countries' export, many of which were members of OECD, and its employment. In this study, the employment model is estimated using a 
fixed-effect model based on panel data estimation techniques, which reveals the effect of different properties between units, allows the degree of freedom to increase, and offers more effective estimators by using cross-section data together. Panel data analysis is a convenient method, because it allows the existence of systematic unobserved differences between units that can be associated with observed factors for evaluate the effects of panel data set. The explanation of variables and data sources are shown in Table 2, the variables in this study consist of employment (number of employed people), GDP per capita (GDP measured in constant 2015 US\$), export (US\$ converted, seasonally adjusted), unit labor cost (employment based on the entire economy), and gross replacement rates in unemployment (based on a one-person unemployment period of at least two months, covering $67 \%$ of the average wage). Trade openness ratio refers to the ratio of sum of imports and exports to GDP, and financial openness expresses the ratio of net financial accounts to GDP.

The findings indicate a negative relationship between the export of 28 OECD countries and its employment. The economic growth, employment level of the past period, trade openness, and exports have an impact on employment. While economic growth, trade openness, and previous employment levels have a positive effect on employment in the current period, exports have a negative effect on employment. In the estimates obtained from the model, the change in labor costs per unit, financial openness, and unemployment payment rates are not meaningful in explaining the change in employment. Among the variables that explain the change in employment, the variable that affects the terms of the coefficient the most is the change in economic growth. This finding contradicts the result of traditional trade theories. However, no significant relationship between exports and employment was found as well in some studies, which states that exports negatively affect employment. Our estimation results are in line with Greenway et al. (1991), Jenkins (2004), Were (2011), Aktakaş et al. (2013), and Ko et al. (2015).

It is critical to adapt to rapidly changing market demands and to create a competitive environment that can encourage adaptations. Policymakers and social partners have a key role to play through active cooperation in connecting education and training systems to industry and matching labor supply to demand. This study has only assessed the effective export on employment in the context of a macro perspective, but a possible link between employment in the services sector, export, and the skilled labor demand has not been considered. Therefore to investigate the effect of exports on the employment level of the services sectors in 28 OECD countries may provide more specific findings. Also, this study contributes to the research in terms of revealing the static effect of export on employment. Finally, we think that research helps us deal with all aspects of this issue when we investigate the dynamic effect of export on employment in the context of services sectors for 28 OECD countries. 
The Coronavirus disease 2019 (COVID-19) is an unprecedented global shock involving simultaneous cuts in both supply and demand in an interconnected world economy. The pandemic points to a transformation in many topics specific to labor markets such as unemployment, new forms of work, and wage regulations. Therefore, future research should analyze the relationship between exports and home office work, and new forms of employment and unemployment, including the effects of the COVID-19 global pandemic. Studying this phenomenon in conjunction with global shocks can be useful to advance understanding of this phenomenon and can generalize research findings. 


\section{Giriş}

İhracatın istihdam üzerinde doğurduğu etkiler çok uzun süredir tartışılmasına rağmen yapılan araştırmalar tek bir sonuç üzerinde uzlaşılamadığını göstermektedir. İhracatın istihdam ile olan ilişkisi geleneksel ticaret teorilerinin varsayımları 1şığında analiz edilmeye başlanmıştır. Geleneksel ticaret modelleri, ticaretin bir ekonomideki genel istihdam seviyesi üzerindeki etkisini doğrudan ele almamakla birlikte, göreceli işgücü talebi hakkında bazı öngörüler sağlamıştır. Gelişmekte olan ülkeler, bol olarak bulunan faktörün kullanıldığ 1 ürünleri üretmekte ve bu ürünlerin ihracatında karşılaştırmalı üstünlük elde etmektedir (Heckscher, 1949). Gelişmekte olan ülkelerde emek faktörü sermayeye görece fazla olduğundan bu faktörü kullanan malların ihracatı yoğun bir şekilde artmakta ve artan uluslararası ticaretle birlikte vasıfsız işgücüne olan talep de artmaktadır. Gelişmekte olan ülkelerde emek talebinin artmasına bağlı olarak açıklanan ihracat ve istihdam ilişkisi, Stolper-Samuelson (1941)'un ortaya koyduğu gelir dağılımına vurgu yapan teori ile literatüre yeni bir bakış sağlamıştır. İthalat eğilimli sektörlerde emeğin korunması azalmakta ve azalan emek talebi emeğin gelirinin, üretiminin ve istihdamın azalmasıyla sonuçlanmaktadır. İhracata dönük sektörlerde ise uluslararası rekabete giren firmalarda artan emek talebi emeğin gelirini, üretimi ve istihdamı artırmaktadır. Az gelişmiş ve gelişmekte olan ülkelerde ihracat artışının istihdam yaratıcı etkisi farklı mekanizmalar yoluyla gerçekleşmektedir. Az gelişmiş ülkelerde ihracatın artması, ticaretin yokluğunda kullanılmayacak olan fazla kaynakların çıktılarına yönelik yeni etkin talebi sağlamak için verilen kaynakları yeniden tahsis edilmesiyle gerçekleşmemektedir. Aksine, yerli üretimi zorunlu olarak azaltmadan, ihracat, üretimi az gelişmiş ülkelerde artırılabilmekte ve istihdam artışı sağlamaktadır (Myint, 1958).

Yeni dış ticaret teorileri, geleneksel dış ticaret modellerinin kabul ettiği ölçeğe göre sabit getiri ve tam istihdam gibi temel varsayımlar yerine eksik rekabet piyasaları ve ölçeğe göre artan getiri varsayımlarını benimsemiştir (Krugman, 1979). Bu varsayımlara dayalı olarak geliştirilen dış ticaret modelleri endüstri ve firma düzeyinde analizler yardımıyla sektörel ihracatın istihdam üzerindeki etkilerini incelemiştir. Çünkü bir ülkede dış ticarette serbestleşme sonrasında yaşanan istihdamdaki genişlemenin ne kadarının ihracat artışına bağlı olarak gerçekleştiğinin tespiti mikro veriler ile analiz yapmayı gerektirmiştir (Khan, 1991; Greenway, Robert, \& Wright, 1999; Erlat, 2000; Jenkins, 2004; Feenstra \& Hong, 2007; Aswicahyono, Brooks, \& Manning, 2011; Aktakaş, Mike, Aytun, \& Laleh, 2013; Akkuş, 2014; Nguyen, 2015; Tandoğan, 2019). İhracat artışlarının istihdam üzerinde negatif etki oluşturduğunu ortaya koyan çalışmaların (Greenaway ve ark., 1999; Jenkins, 2004; Aktakas ve ark., 2013; Ko, Rangkakulnuwat, \& Paweenawat, 2015) yanı sıra ihracat artışları ve istihdam arasında korelasyon bulunmadığı sonucuna ulaşan çalışmalar da yer almaktadır (Edwards, 2004; Hoekman \& Winters, 2005; McMillan \& Verduzco, 2011). 
Dünyadaki birçok ülkenin ticaret performansı son yirmi yılda dinamik olarak iyileşmesine rağmen, istihdam yaratma ve beceri talebi üzerindeki etkileri ülkeler arasında karmaşık hale gelmiştir. Gelişmekte olan ülkelerde, özellikle imalat sanayi sektöründeki ihracat artışları başlangıçta düşük vasıflı emek talebini artırmaktadır. Bu, çoğunlukla düşük vasıflı emek gerektiren işlerin yapıldığı tekstil, hazır, giyim, plastik, işlenmiş gıda gibi sektörlerde söz konusudur. Sektörün üretim yapısındaki değişiklik ve teknolojik sistemlerin üretim süreçlerinde yoğunlaştırılmasıyla düşük vasıflı emeğin istihdamı azalmaktadır. Bu süreç ilgili ihracat sektöründe daha sermaye yoğun üretimin ve vasıflı emek talebinin artması ile devam etmektedir (ILO, 2017). Çalışma dünyasında değişimin hızlandığı bu çağda, hem işçiler hem de işverenler için işgücü piyasasının gerekli kıldığı beceri ve nitelikleri sağlayabilmesi için gerekli sistemlerin güçlendirilmesi önem arz etmektedir. Bu bağlamda gelişmekte olan birçok ülkede imalat sektörü ihracatının istihdam artışlarına katkı sunduğu gerçeği veriyken, ihracat sektörlerinin diğer sektörler üzerinde istihdam yaratma konusunda pozitif dışsallık sunduğu güncel literatürün odağındadır. Özellikle imalat sektörü ihracat artışları hizmetler sektöründe iş yaratma ve istihdam alanı oluşturma potansiyeli yüksek sektörlerdendir (Konan \& Masakus, 2006; Aswicahyono ve ark., 2011).

İhracatın istihdam üzerinde oluşturduğu pozitif etki literatürde yaygın görüş olarak karşımıza çıkmaktadır. Buna bağlı olarak, çalışmamızın başlıca motivasyonu OECD ülkelerinde 2001-2019 yıllarında ihracatın ve istihdam değişimleri/büyümesi verisi ışığında, ihracat büyümesinin toplam ekonomideki istihdam seviyesinde değişim oluşturup oluşturmadığıdır. Bu aşamayı takiben çalışmamız “28 OECD ülkesinin¹ 2001-2019 yıllarındaki ihracat büyümesinin istihdam büyümesi üzerindeki etkisi ne olmuştur?” soruna cevap vermek üzere amaç ve hedeflerini oluşturmuştur. Çalışmanın amacı, 28 OECD üyesi ülkenin mal ihracatındaki değişimlerin toplam istihdam değişimleri üzerindeki etkisini araştırmaktır. Bu amaç perspektifinde çalışmanın hedefleri, ihracat ve istihdam arasındaki ilişkinin teorik temellerinin ortaya konulması ve ihracat değişimlerinin istihdam üzerindeki etkisinin ampirik olarak analiz edilmesidir. Bu bağlamda çalışma, OECD ülkelerindeki ihracat büyümesinin istihdam büyümesi üzerinde pozitif etki oluşturduğu temel hipotezini OECD ülkelerindeki ihracat büyümesinin istihdam büyümesi üzerinde negatif etki oluşturduğunu ifade eden alternatif hipoteze karşılık test etmektedir. Çalışmada ortaya konulmuş olan hipotezler, birimler arası farklı özelliklerin etkisini ortaya koyan, yatay kesit ve zaman serisi verisinin birlikte kullanılmasıyla serbestlik derecesinin artmasına olanak tanıyan ve bu nedenle daha etkin tahminciler sunan panel veri tahmin yöntemi uygulamasıyla test edilmiştir. İhracat artışlarının istihdam üzerindeki etkileri birçok çalışmada endüstriyel

\footnotetext{
${ }^{1}$ Avustralya, Avusturya, Belçika, Kanada, Çek Cumhuriyeti, Estonya, Finlandiya, Fransa, Almanya, Yunanistan, Macaristan, İrlanda, İsrail, İtalya, Japonya, Kore, Letonya, Lüksemburg, Yeni Zelanda, Norveç, Portekiz, Slovenya, İspanya, İsveç, İsviçre, Türkiye, Birleşik Krallık ve Amerika Birleşik Devletleri.
} 
ya da firma düzeyinde girdi çıktı analizleri ile araştırılmıştır. Bu çalışma çok sayıda ülkenin ekonomik büyüme, birim başına emek maliyetleri, işsizlik ödemesi, ticari açıklık ve finansal açıklık oranları gibi makro düzeyde verilerinden faydalanarak ihracat artışlarının ekonomideki toplam istihdam üzerindeki etkisini ölçmesi yönüyle anahtar role sahiptir. Çalışma süresi ve veri erişiminin imkan verdiği ölçüde oluşturulan veri seti, OECD üyesi 28 ülkenin analiz kapsamına alınmasına olanak tanımıştır.

Çalışmada öncelikle ihracat ve istihdam ilişkisinin ortaya konulmasında teorik ve uygulamalı araştırmaların elde ettiği bulgular ve güncel eğilimler anlatılmıştır. Daha sonra uygulamalı analiz için faydalanılan panel veri tahmin teknikleri ve aşamaları test sonuçları ile birlikte sunulmuştur. Analiz sonucunda elde edilen bulgular, sonuç ve öneriler bölümünde teorik ve var olan durum yelpazesinde değerlendirilmiştir.

\section{1. İhracatın İstihdam Üzerindeki Etkilerinin Teorik ve Ampirik İncelemesi}

İhracatın istihdam üzerindeki doğrudan ve dolaylı etkileri gerek teorik gerekse de ampirik analizler yoluyla tartışılmaktadır. İhracat ve istihdam ilişkisini incelemek için farklı yaklaşımlar benimsenmesine karşılık şimdiye kadar literatürden net bir sonuç alınamamıştır. $\mathrm{Bu}$ literatüre ilişkin teorik ve uygulamalı sonuçların ortak gösterilebilecek tek sonucu, istihdam etkilerinin ülkeye özgü çok fazla faktörün etkisi altında gelişme göstermesidir. İhracatın istihdam yaratıcı etkisi, büyük ölçüde geleneksel dış ticaret teorilerinin sunduğu teorik temeller üzerinden gelişme göstermiştir. Mutlak Üstünlükler ve Karşılaştırmalı Üstünlükler Teorisi ülkeler arasındaki dış ticaretin nedenini, yurtiçi üretim maliyetlerinin farklılığına dayandırmaktadır. Karşılaştırmalı Üstünlükler Teorisi, dış ticarette üretim faktörü olarak emek verimliliğini dikkate almakta iken emek verimliliğini belirleyen unsurları açıklamamaktadır. Heckscher-Ohlin Karşılaştırmalı Üstünlükler Teorisi'nin temel varsayımları bağlamında ülkelerin neden farklı faktör maliyetlerine sahip olabileceklerini araştırmıştır. Heckscher-Ohlin' in "Faktör Donatımı Teorisi” olarak literatürde yerini alan teori, bir ülkede bol olarak bulunan faktörü yoğun olarak kullandığı mallar bakımından karşılaştırmalı üstünlük elde edeceği hipotezi üzerinde durmaktadır (Heckscher, 1949). Heckscher -Ohlin Teorisi'ni temel alan bir gelir dağılımı teorisi, Stolper ve Samuelson (1941), dış ticaret sonrasında ilgili ülkelerdeki faktör fiyatlarına vurgu yapmaktadır. Bu teori, vasıfsız emeğin ürettiği çıktının fiyatındaki(vasıflı emeğin ürettiği ürünün fiyatına göre) düşüşün vasıfsız emeğin getirisini(vasıflı emeğe göre) düşüreceğini ifade etmektedir. İstihdam ve dış ticaret arasındaki ilişki çoğunlukla Stolper ve Samuelson Teoremi çerçevesinde şekillenmiştir. İthalat eğilimli sektörlerde emeğin korumasının azalmasına bağlı olarak üretim ve istihdam azalırken, ihracata dönük sektörlerde uluslararası rekabete giren firmalarda girdi maliyetlerinin düşmesiyle üretim ve istihdam artmıştır. 
Karşılaştırmalı Üstünlükler Teorisi, Faktör Donatımı Teorisi ve Stolper-Samuelson Teoremi dış ticaret öncesinde ve sonrasında tam istihdam varsayımları dahilinde teorik bulguları ortaya koyarak, ticaret sonrasında üretim faktörlerinin etkin dağılım ve uzmanlaşma ile verimlilik ve çıktı artışına dikkat çekmektedir. Ancak, az gelişmiş ülkelerin verimlilik kapasiteleri gerçekleşenin oldukça üzerinde olduğu realitesinin 1şı̆̆ında, Myint (1958), az gelişmiş ülkelerdeki dış ticaret sonrasında ihracat üretimindeki hızlı artışın, verili kaynak ve teknik gelişime dayalı karşılaştırmalı maliyetler teorisinin beklentilerinden çok başka bir nedene işaret ettiğini ortaya koymaktadır. Bu teori, yerli üretimi zorunlu olarak azaltmadan ihracat üretiminin az gelişmiş ülkelerde artırılabildiğini ifade etmektedir. Diğer taraftan üretim fazlası kapasite ihracat üretimi için kullanılırken, yerli üretim için bir kayıp söz konusu olmamaktadır. Tüm bu faktörler, şimdiye kadar kullanılmamış veya fazla kaynakların artan hacmini ihracat üretimine çekerek devam eden bir genişleme sürecini göstermektedir. Myint (1958) tarafından 'vent for surplus' (VFS) teorisi ve uluslararası ticaretin 'üretkenlik' teorisi, uluslararası ticaretin hareketsiz veya atıl kaynakları harekete geçirdiğini, ihracat için daha fazla ürünün üretmesini ve istihdama katkısına değinmektedir (Nurkse, 1961; Fu \& Balsubramanyam, 2005).

Geleneksel dış ticaret teorilerinin tam istihdam, ölçeğe göre sabit getiri ve faktör hareketliliği gibi varsayımları dışarıda bırakıldığında, birim başına düşen üretim maliyetlerdeki azalma sonucunda endüstriyel uzmanlaşma kendini göstermektedir (Krugman, 1979). Dış ticaretin ülkeler arasında olmaktan çok endüstriler arasında gerçekleşen bir olgu olduğunu ifade eden yeni dış ticaret teorileri, firma düzeyinde elde edilen verilerle ihracatın istihdam üzerindeki etkilerini incelemiştir. Vasıfsız işçilerin nispi istihdamındaki artış ve buna bağlı olarak yüksek vasıflı ve düşük vasıflı işçiler arasındaki ücret farkındaki artış, büyük ölçüde ihracatçı işletmelerdeki farklılıktan kaynaklanmaktadır. Firma seviyesindeki verilerden yola çıkan Bernard ve Jensen (1997), artan vasıflı işgücü talebinin veya beceri geliştirmenin büyük bir kısmının endüstrilerde ortaya çıktığını vurgulamıştır. İhracatçı firmaların sayılarındaki artış, nitelikli ve vasıflı emek talebini artırmaktadır. Diğer taraftan Bernard, Jensen, Redding, ve Schott (2007), ihracat piyasalarına giriş yapan firmaların istihdam oranlarındaki iyileşmenin girmeyen firmalara göre daha yüksek olduğunu vurgulamıştır. İhracatın istihdam üzerindeki etkisi çoğunlukla üretim ve ekonomik büyümenin artması ile gerçekleşen mekanizmaya dayandırılmaktadır. Nitekim Melitz (2003), yerli firmaların uluslararası ticarete katılımının o ülkenin ortalama üretkenliğini artırdığını göstermiştir. Uluslararası rekabet karşısında daha üretken firmalar genişlerken, daha yüksek ithalat rekabeti nedeniyle daha az üretken firmalar küçülmektedir. Firmaların heterojenliğini hesaba katan araştırmalara göre, yalnızca bir endüstrideki daha üretken işletmeler, artan uluslararası ticarete maruz kalma durumunda ihracat yapma eğilimindedir (Bernard ve ark., 2007). İhracatçı firmaların istihdam ve çıktı büyüme oranları 
daha yüksek olmakta ve istihdam artışı dış pazarlara girdikten sonra da artmaya devam etmektedir (ILO, 2007).

D1ş ticaret sonrasında ihracat yapan sektörlerin üretimi ve işgücü talebi artarken, ithalatla rekabet eden sektörlerde üretim azalmakta ve istihdamda azalma meydana gelmektedir. İhracata yönelik olan ve ithalatla rekabet eden sektörlerin farklı işçi türlerini istihdam ettiği veya farklı oranlarda istihdam ettiği varsayıldığından, ticaretin serbestleştirilmesi uzun vadede farklı işçi türleri için nispi talebi etkilemektedir (ILO, 2007). Sektörler arası bir hareket, işçiler için daha yüksek yeniden eğitim maliyetleri ve daha uzun arama süreleri anlamına gelmektedir. Bu durumda sadece sektörler arasında değil aynı zamanda sektörler içinde de işgücünün yeniden dağılımı gündeme gelmektedir. Örneğin, işgücü arzının oldukça esnek olduğu ekonomilerde kırsal alanlarda büyük bir gizli işgücü arzı olduğu için, ihracatçılar bu kırsal alanlardan işçileri mevcut ücret oranlarıyla çekerek üretimi artırabilirler. Dolayısıyla ticaretin serbestleştirilmesi, ücretlerdeki değişikliklerden ziyade kayıtlı istihdam seviyelerinde artışlara yol açmaktadır. Daha öncesinde de değinildiği gibi, ihracatın istihdam üzerindeki etkisi ülkelerin makro-ekonomik özelliklerine bağlı olarak gerçekleşmektedir. Ülkelerin işgücü piyasasında var olan politikalar ve uygulamalar ihracatın istihdam üzerinde farklı sonuçlar doğurmaktadır. Asgari ücret uygulamaları belirli işçi türleri için ücretleri denge düzeyinin üzerinde tutar ve işgücü arzı iş gücü talebini aşarak işsizlik ortaya çıkar. Bu işçiler ağırlıklı olarak ithalatla rekabet eden sektörlerde aktiflerse, ticaretin serbestleştirilmesi bu işçilere olan talebi daha da azaltacak ve işsizlik artacaktır. Örneğin, sanayileşmiş ülkelerde düşük vasıflı işçiler için asgari ücret, işverenlerin ödemeye razı geldikleri ücretten daha yüksekse, bu ülkelerde düşük vasıflı işçilerin işsizliğinin artmasıyla sonuçlanabilir. Etkin ücret modelinin uygulandığı işgücü piyasalarında ise, işverenler çalışan verimliliklerini artırmak için asgari ücret ya da piyasa denge ücret seviyesinin üzerinde ücretler ödemektedir. Böyle bir durumda ihracatın artması, farklı işçi türleri için nispi talebi artırdığından istihdama katkı sunması beklenmektedir.

D1ş ticaret ülkelerin ekonomik büyümelerine katkı sunarken bu büyümenin kapsayıcılığ1 ve istihdam üzerindeki etkileri uzun süredir tartışılmaktadır (UNCTAD, 2018). İşsiz büyümenin yaygın olduğu mevcut dünya ekonomisinde rekabetçi bir hizmet sektörü, büyümenin önemli bir belirleyicisidir. Geleneksel ticaret teorileri mal ihracatının istihdamda daha büyük bir artış yüzdesine işaret etse de, hizmetler sektörü, imalat sektöründen daha fazla sayıda iş yaratma potansiyeline sahiptir. İhracat yapan imalat sanayi sektörlerinin üretimi aynı zamanda artan girdi talebi yoluyla diğer sanayi ve hizmetler sektörünü etkilemektedir (ILO, 2018). Hoekman'a (2006) göre, herhangi bir ürünün üretim zinciri ArGe, finans, tasarım, pazarlama, dağıtım ve ürün/marka yönetimi gibi hizmet faaliyetleri, ihracat yapan imalat sektöründe gerçekleşmesi beklenen istihdam artışına katkı sunabilmektedir. Konan ve Masakus (2006), hizmetler sektöründeki düşük ayarlama 
maliyetlerinin, mal ticaretine kıyasla hizmet ticaretinin serbestleştirilmesinden görece daha yüksek istihdam kazançlarına katkıda bulunduğunu öne sürmektedir. Serbestleşmeden çok sonra bile, hizmetlerin yerel olarak sağlanmaya devam etmesi yurt içi istihdama katk1 sunması anlamına gelmektedir. Aswicahyono ve ark. (2011), Endonezya'nın ana ihracat endüstrileriyle dolaylı bağlantılar nedeniyle hizmetler sektöründeki yeni iş oluşumlarındaki artışa bağlı olarak hizmetler sektöründeki istihdamın gelişimini doğrulamıştır. Yine Ghani (2010), Hindistan'da 1998-2008 yıllarında hizmet ihracatının istihdamı artırıcı etkisini gelişmekte olan ülkeler için başarılı bir hizmet odaklı büyüme örneği olarak tartışmaktadır.

Genellikle ticaretin istihdam üzerindeki etkisinin çözülmesini zorlaştıran husus, diğer reform ve makroekonomik değişikliklerin birlikte uygulanmasıdır (UNCTAD, 2018). Bu nedenle ihracat artışları her zaman istihdam artışlarını beraberinde getirmemektedir. McMillan ve Verduzco (2011), birçok gelişmekte olan ülkeyi kapsayan verileri kullanarak 1980 ile 2006 arasında ticaretin serbestleştirilmesi ile endüstriyel istihdam arasında bir korelasyon tespit edememiştir. Benzer şekilde, farklı bir veri seti kullanan OECD (2007), 1995 ve 2005 yılları için istihdamdaki değişim ile ticarete açıklık arasında önemli bir korelasyon bulunmadığını ortaya koymuştur. Hoekman ve Winters (2005), ihracat sektörlerinde istihdamın azaldığını ve bunun önemli bir nedeninin, ithalat rekabetinin arttığ sektörlerde yerinden edilmiş işçilerin ihracatçı sektörler tarafından kolayca istihdam edilememesi olduğunu vurgulamaktadır. İhracat yapan sektörlerin uluslararası rekabet için teknolojik değişim sürecini pekiştirmeleri ile mümkün olmaktadır. Teknolojik değişimin istihdam üzerindeki etkisi bu teknolojik değişimin niteliğine bağlı olmaktadır. Hicks-nötr teknolojik değişim, çıktı birimi başına hem vasıflı hem de vasıfsı işgücü istihdamını azaltmaktadır. Edwards (2004), ticaretin serbestleştirilmesi ile büyük firmaların istihdamı arasında negatif bir ilişki bulmaktadır. Küçük firmalar arasında ise bu ilişki bulunmamıştır. Ticaretin serbestleştirilmesinin istihdam üzerindeki olası etkisi, artan ithalat rekabetine yanıt olarak firmaların kapatılmasıyla istihdamın azalmasıdır. Ticaretin serbestleştirilmesi sürecinden kaynaklanan ihracat artışı rekabet gücünü iyileştirmesine rağmen, ihracat sektörlerinde istihdamda, özellikle vasıfsız işgücünde önemli düşüşler yaşanmaktadır. İstihdamdaki düşüş, ihracatçı firmaların işgücü verimliliğini artırmak için üretimin yeniden yapılandırılmasını yansıtmaktadır. Diğer taraftan ihracat yapan sektörler diğer firmalarla karşılaştırıldığında görece beceri yoğun olup, bu firmalar içerisinde üretimin yeniden yapılandırılması ve yeni teknolojinin benimsenmesi vasıflı işgücü talebini artırmaktadır. İhracat yapan sektörlerin vasıflı emek talebinin doğurduğu en önemli sonuç, ihracatta büyüme yoluyla vasıfsız istihdam yaratmanın giderek daha zor hale gelmesidir.

D1ş ticarette serbestleşme ile artan ihracatın istihdam üzerindeki etkilerini inceleyen çok sayıda araştırma yapılmıştır. Bu çalışmanın oluşturulması süresince incelenen ve faydalanılan diğer araştırmaların analiz yöntemleri, incelenen dönem, örneklem ve bulguları Tablo 1'de sunulmuştur. 
Tablo 1: İhracat ve İstihdam İlişkisi Üzerine Detaylı Literatür İncelemesi

\begin{tabular}{|c|c|c|c|}
\hline Yazarlar & $\begin{array}{l}\text { Analiz Edilen } \\
\text { Dönem }\end{array}$ & $\begin{array}{l}\text { Analiz } \\
\text { Yöntemi }\end{array}$ & Bulgular \\
\hline Khan (1991) & $\begin{array}{l}\text { 1972-1988; } \\
\text { Pakistan }\end{array}$ & $\begin{array}{l}\text { Girdi-çıktı } \\
\text { analizi }\end{array}$ & $\begin{array}{l}\text { İhracat, istihdamı doğrudan olduğu kadar çıktı yoluyla } \\
\text { da etkilemektedir. İhracat performansı ile GSYİH } \\
\text { büyümesi arasında güçlü bir ilişki bulunmuştur. } \\
\text { Üretilen ihracat, işgücüne istihdam sağlayan önemli bir } \\
\text { sektör olma potansiyelini yansıtmaktadır. Mamul mal } \\
\text { ihracatında yüzde 1'lik bir artışın istihdamda yüzde } 0,6 \\
\text { artışa yol açtığı tespit edilmiştir. }\end{array}$ \\
\hline $\begin{array}{l}\text { Greenaway ve ark. } \\
\text { (1999) }\end{array}$ & $\begin{array}{c}\text { 1979-1991; } \\
\text { UK'de imalat } \\
\text { sanayi sektöründe } \\
\text { faaliyet gösteren } \\
167 \text { firma }\end{array}$ & $\begin{array}{l}\text { Panel veri } \\
\text { analizi }\end{array}$ & İhracatın istihdam üzerinde negatif etkisi vardır. \\
\hline Erlat (2000) & $\begin{array}{c}\text { (1969-1978, } \\
\text { 1979-1981, } \\
\text { 1982-1990, 1991- } \\
\text { 1994); Türkiye }\end{array}$ & $\begin{array}{l}\text { Hesaplama } \\
\text { yöntemleriyle } \\
\text { analiz }\end{array}$ & $\begin{array}{l}\text { İhracata dayalı istihdamda 1978-1982 kriz döneminde } \\
\text { küçük ama yine de olumlu bir değişiklik olmuştur. } \\
\text { İtihdamdaki azalmanın kaynağı ise ithalatın yer } \\
\text { değiştirme etkisi olarak vurgulanmıştır. } \\
\text { Son dönem olan } 1991 \text { - 1994, yine bir kriz dönemidir } \\
\text { ve istihdamda azalma yerine ihracata bağlı artışın } \\
\text { olduğu tespit edilmiştir. }\end{array}$ \\
\hline Jenkins (2004) & $\begin{array}{l}\text { 1995-1999; } \\
\text { Vietnam } 4 \\
\text { madencilik, } 21 \\
\text { imalat sanayi } \\
\text { sektöründe } \\
\text { faaliyet gösteren } \\
\quad \text { firma }\end{array}$ & $\begin{array}{l}\text { Panel veri } \\
\text { analizi }\end{array}$ & $\begin{array}{l}\text { İhracat hacminin istihdam üzerinde negatif etkisi } \\
\text { bulunmaktadır. }\end{array}$ \\
\hline $\begin{array}{l}\text { Feenstra ve Hong } \\
(2007)\end{array}$ & $1997-2002$ & $\begin{array}{l}\text { Girdi-çıktı } \\
\text { analizi }\end{array}$ & $\begin{array}{c}\text { 1997-2002 yılları arasındaki ihracat büyümesinin yılda } \\
\text { en fazla 2,5 milyon işe katkıda bulunduğu ve istihdam } \\
\text { kazançlarının çoğunun inşaat gibi ticareti yapılmayan } \\
\text { mallardan geldiği tahmin edilmiştir. İhracat, 2000- } \\
2005 \text { döneminde çok daha hızlı büyümüştür, bu } \\
\text { da istihdamdaki artışın önemli bir bölümünü } \\
\text { açıklamaktadır. }\end{array}$ \\
\hline $\begin{array}{l}\text { Akcoraoglu ve } \\
\text { Acikgoz (2011) }\end{array}$ & $\begin{array}{l}\text { 1990:Q1- } \\
\text { 2010:Q2; Türkiye }\end{array}$ & $\begin{array}{l}\text { ARDL sınır } \\
\text { testi yaklaşımı }\end{array}$ & $\begin{array}{c}\text { İstihdam ve ihracat arasında uzun dönemde anlamlı ve } \\
\text { pozitif bir ilişki vardır. Hem kısa dönemde hem uzun } \\
\text { dönemde ihracattan istihdama tek yönlü bir nedensellik } \\
\text { bulunmaktadır. }\end{array}$ \\
\hline $\begin{array}{l}\text { Polat ve Uslu } \\
\text { (2011) }\end{array}$ & $\begin{array}{l}\text { 1992-2001; } \\
\text { Türkiye imalat } \\
\quad \text { sektörü }\end{array}$ & $\begin{array}{l}\text { Dinamik Panel } \\
\text { veri analizi }\end{array}$ & $\begin{array}{c}\text { İhracat, istihdamı pozitif olarak etkilemektedir. İzleyen } \\
\text { yıllarda istihdamdaki artış cari yıldaki ihracatın } \\
\text { artışından kaynaklanmaktadır. }\end{array}$ \\
\hline $\begin{array}{l}\text { Polat ve ark. } \\
(2011)\end{array}$ & $\begin{array}{l}\text { 2003-2008; } \\
\text { Türkiye'de } 22 \\
\text { imalat sanayi } \\
\text { sektörü firmas1 }\end{array}$ & $\begin{array}{l}\text { Panel veri } \\
\text { analizi }\end{array}$ & $\begin{array}{l}\text { İhracat ve istihdam arasında istatistiksel olarak } \\
\text { anlamsız bir ilişki vardır. }\end{array}$ \\
\hline
\end{tabular}




\section{Yöntem ve Model}

Bu çalışma, 28 OECD üyesi ülkenin ihracat büyümesinin istihdam büyümesi üzerindeki etkisini araştırmaktadır ve 2001-2019 dönemini kapsayan yıllık verileri kullanmaktadır. İhracat miktarları olarak kullanılan veri seti mal ihracatından elde edilen verileri kapsamaktadır. Bunun başlıca sebebi, OECD ülkelerinin mal ihracatı ile hizmetler ihracatı miktarlarının karşılaştırmasında mal ihracatının hizmet ihracatının çok üzerinde gerçekleşmesidir (Grafik 1'de gösterilmiştir). OECD ülkelerinde ihracat değişimleri ile istihdam değişimlerinin paralel seyir izlediği Grafik 2 'de sunulmuştur.

Grafik 1: Toplam İhracat İçinde Mal ve Hizmetler İhracatı Seviyesi (2005-2019)

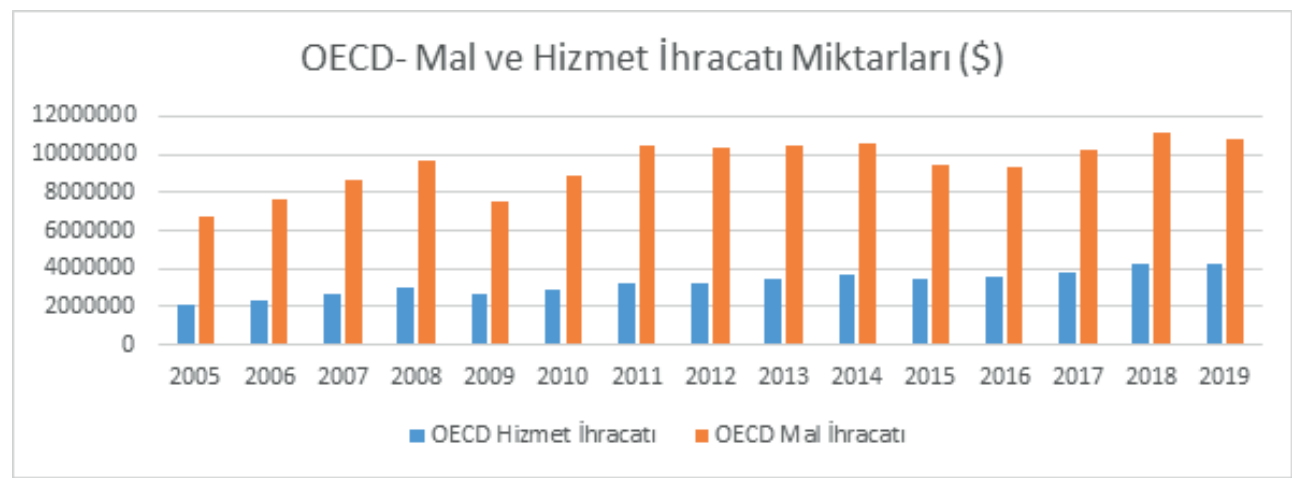

Kaynak: OECD.stat

$\mathrm{Bu}$ çalışmanın motivasyonu OECD ülkelerinde ihracatın ve istihdam artışlarının verisi 1şığında, ihracat büyümesinin toplam ekonomideki istihdam seviyesinde değişim oluşturup oluşturmadığıdır. Bu bağlamda önsel değerlendirmeler itibariyle, OECD ülkelerinde ihracat değişimleri ile istihdam değişimlerinin paralel seyir izlediği Grafik 2 'de sunulmuştur.

Grafik 2: Mal İhracatı ve İstihdamın Önceki Yıla Göre Değişimleri (2008-2019)

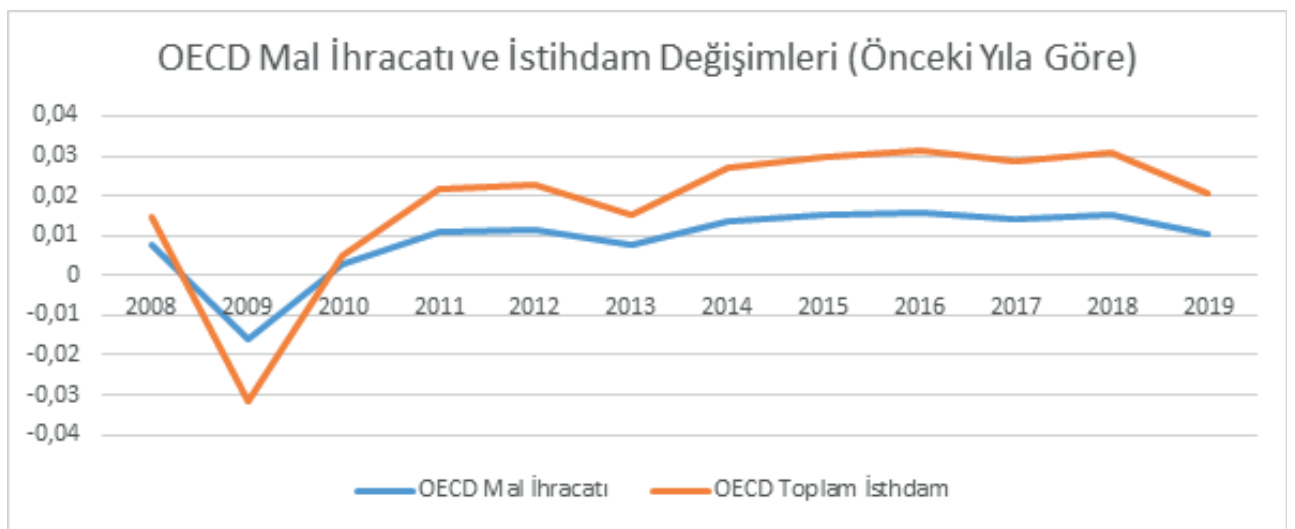

Kaynak: OECD.stat 
İhracat değişiminin istihdam değişimi üzerindeki etkilerini incelemek için kurulan modelde yer alan değişkenlerin tanımları, kaynakları ve özet istatistikler Tablo 2'de yer almaktadır.

$$
\begin{aligned}
& \ln \Delta \text { istihdam }_{\text {it }}=\alpha+\beta_{1} \ln \Delta \text { istihdam }_{\text {it- } 1}+\beta_{2} \ln \Delta \text { ihracat }_{\text {it }}+\beta_{3} \ln \Delta \text { emekmaliyet }_{\text {it }}+ \\
& \beta_{4} \ln \Delta \mathrm{GSYIIH}_{\mathrm{it}}+\beta_{5} \ln \Delta \text { işsizliködemesi } \mathrm{i}_{\mathrm{it}}+\beta_{6} \ln \Delta \text { ticariaçıklık } \mathrm{it}_{\mathrm{it}}+\beta_{7} \ln \Delta \text { finansalaçıklık } \mathrm{it}_{\mathrm{it}}+\varepsilon_{\mathrm{it}}
\end{aligned}
$$

(1). eşitlikte verilen modelde bağımlı değişken olarak yer alan $\ln \Delta$ istihdam ${ }_{i t}, t$ döneminde i ülkesinin istihdamındaki büyümeyi ifade etmektedir. Modelin bağımsız değişkenleri: $\ln \Delta$ istihdam $_{\text {it-1 }}, \mathrm{t}-1$ döneminde i ülkesinin istihdam büyümesini, $\ln \Delta$ ihracat $_{i t}$, $\mathrm{i}$ ülkesinin $\mathrm{t}$ döneminde ihracat büyümesini, lnemekmaliyet ${ }_{i t}$, $i$ ülkesinin $t$ döneminde emek birim maliyetlerindeki büyümeyi, $\ln \Delta \mathrm{GSYIH} \mathrm{H}_{\mathrm{it}}$, ülkesinin $\mathrm{t}$ döneminde GSYİH büyümesini ve $\ln \Delta$ işsizliködemes $i_{i}$,, ülkesinin $t$ döneminde işsizlik ödemesi oranındaki büyümeyi göstermektedir. $\ln \Delta$ ticariaçıklık $k_{\text {it }}$ i ülkesinin $t$ döneminde ithalat ve ihracat toplamının GSYİH'ya oranınındaki büyüme, $\ln \Delta$ finansalaçıklık ${ }_{i t}$ ise net finans hesabının GSYİH'ye oranındaki büyümeyi ifade etmektedir. Modelde yer alan tüm değişkenler doğal logaritmik formdadır. $\ln \Delta$ istihdam $_{\mathrm{it}}, \mathrm{t}$ ylındaki istihdamın $\mathrm{t}-1$ yılına göre değişimini ifade etmektedir. Daha açık bir ifade ile yapılan dönüşüm, $\ln \left(\right.$ istihdam $_{\mathrm{t}} /$ istihdam $_{\mathrm{t}-1}$ ) biçimindedir. Tüm değişkenler t-1 dönemine göre $t$ dönemindeki değişimi ifade edecek biçimde oluşturulmuştur.

İstihdamın bir önceki döneme ait gözlem değerlerinin cari istihdam değerlerini pozitif yönde etkilemesi, ihracattaki pozitif yöndeki bir değişimin istihdamı pozitif yönde etkilemesi beklenmektedir. Emek birim maliyetlerindeki azalmanın istihdam üzerindeki etkisi firma yahut sektörlerin niteliklerine göre pozitif ya da negatif yönde beklenmektedir. İşsizlik ödemeleri istihdamı bazı durumlarda negatif yönde etkilerken; bazı hallerde pozitif yönde etkilemektedir. Çalışanlara işsizlik süresince sağlanan gelir, gelirin sağlanacağı süre boyunca iş aramamasına ve istihdam edilmemesine yol açabilmektedir. Diğer taraftan işsizlik ödemesi kayıtlı istihdam oranını artırmaktadır. Nitekim işsiz kaldığında gelir garantisi altında olacağını bilen çalışanlar kayıtlı istihdam edilme yolunu tercih edeceklerdir. Bu yönüyle ise işsizlik ödemelerinin istihdam üzerinde pozitif etkisi ortaya çıkmaktadır. Bu etkinin negatif ya da pozitif olması, bir ülkenin istihdam yapısı, işgücü örgütlenme yapısı, kültürel kodları, kamu denetimleri ve işsizlik ödemelerinin süre ve miktarlarına bağlı olarak değişkenlik sergilemektedir. Ticari açıklık oranı ihracat ve ithalat kalemlerini de içermesi nedeniyle ihracat ve ithalatın istihdam üzerindeki etkisine paralel sonuçlar vermesi beklenmektedir. Finansal açıklık oranının istihdam üzerindeki beklenen etkisi ülkelerin diğer makro değişkenleri ile ilişkili olarak negatif ya da pozitif yönde olabilmektedir.

İhracattaki büyümenin istihdam büyümesi üzerindeki etkisinin modellemesinde çeşitli 


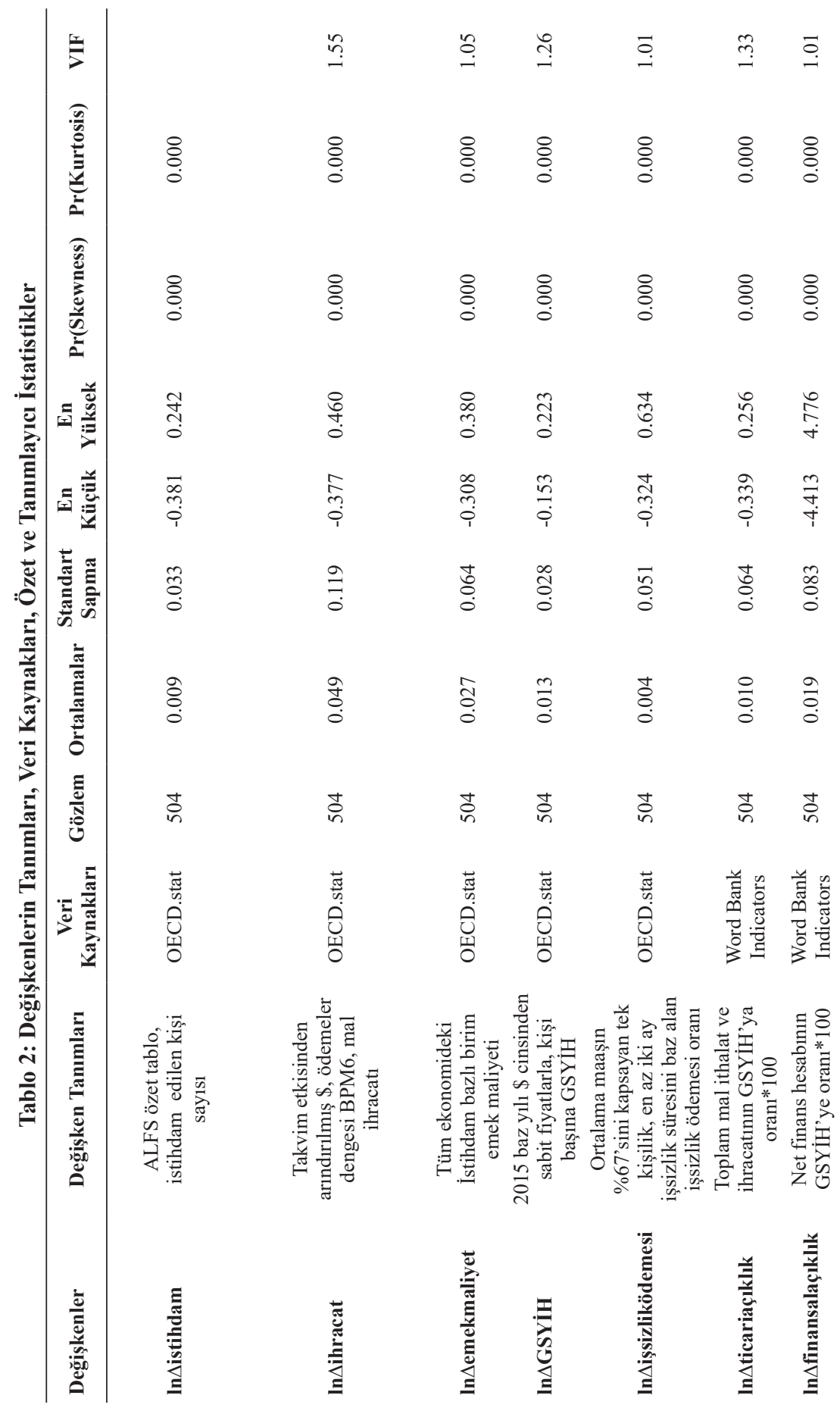




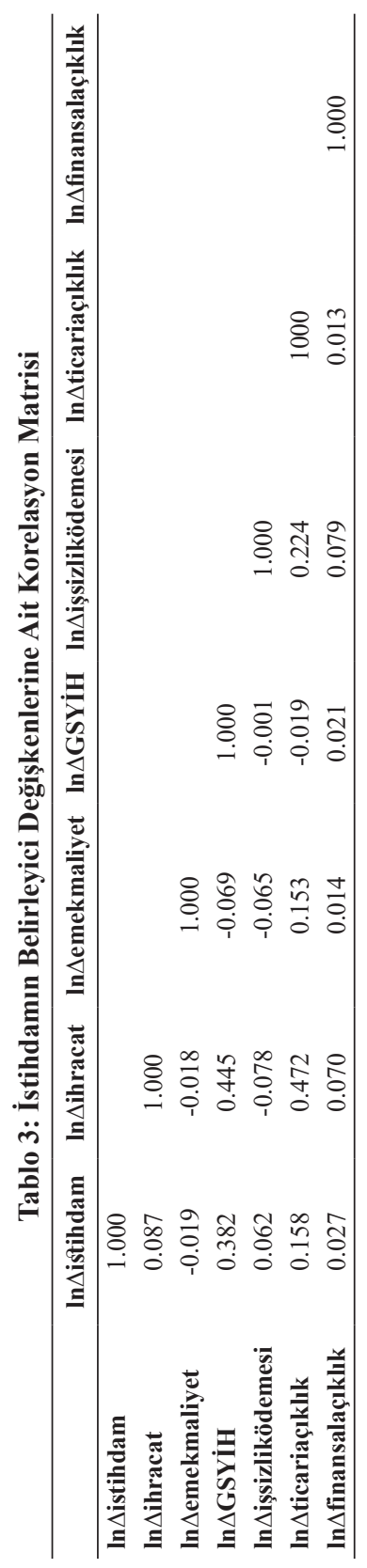

açıklayıcı değişkenlerden faydalanılmıştır. Bu açıklayıcı değiş̧enlerin birbirleri arasındaki ve açıklanan değişkenler arasındaki korelasyon Tablo 3'de sunulmuştur. Tablo 2 ve Tablo 3 'de verilen özet istatistikler ve korelasyon ilişkisi, değişkenler arasındaki ilişkiyi ortaya 
koyan önsel bilgi niteliğindedir. Ancak ihracat büyümesinin istihdamdaki büyüme üzerindeki etkilerinin model dahilinde incelemek için uygun ekonometrik yöntemler ile analiz edilmesi gerekmektedir.

İhracat büyümesi ve istihdam büyümesi arasındaki statik ilişkiyi incelemek için panel veri tahmin tekniklerinden faydalanılmıştır. Panel veri analizi, araştırmacılara daha fazla veri ile çalışma firsatı sağlamaktadır. Hem zaman serisi hem de yatay kesit verinin birlikte kullanılmasıyla, serbestlik derecesi artmakta, bağımsız değişkenler arasındaki çoklu bağlantı azaltılmakta ve böylelikle elde edilen tahminlerin etkinliği artmaktadır (Hsiao, 2003). Yatay kesit veriler ile çalışıldığında sapmalı sonuçlar tahmin edilmesine neden olan heterojenlik riski modele dahil edilemezken, panel veri kullanımıyla birey, firma, ülke gibi birimlerin heterojenliği kontrol edilebilmektedir (Baltagi, 2005). Zaman serisi verileri mikro-ekonomik ve sosyo-demografik unsurların etki alanını ortaya koymak konusunda yetersiz kalırken, yatay kesit veri de mikro-ekonomik ve sosyo-demografik faktörlerin etki alanını ifade etmekte zamana bağlı etkiyi içermemektedir. Yatay kesit veriler birimler arası farklı özelliklerin etkisini ortaya koymaktadır. Zaman serisi verilerine dayalı modellerde ise birim özellikleri yansıtılmaktadır. Dolayısıyla, panel veri birim ve birimler arasındaki farklılıkların etkisini eş zamanda ortaya koymaktadır (Yerdelen, 2016).

Panel veri analizinde kullanılan tahmin yöntemi panel veri modeline göre değişkenlik göstermektedir. Havuzlanmış en küçük kareler yöntemi ile tahmin edilen klasik modelde birim ve zaman etkilerin bulunmadığı varsayılmaktadır. Birim ve zaman etkilerinden biri ya da ikisini içeren modellerde ise sabit etkiler tahmincisi ile tesadüfi etkiler tahmincisi tercih edilebilmektedir. Yatay kesit veri, ana kütleden tesadüfi biçimde elde ediliyorsa tesadüfi etkileri, ancak daha özel bir veri seti oluşturulmuşsa sabit etkiler tahmincisini tercih etmek uygun olacaktır. Tesadüfi etkiler ve sabit etkiler modeli arasındaki en büyük ayırım, tesadüfi etkilerde bağımsız değişkenler ve birim etkiler arasındaki korelasyonun bulunmadığı varsayımıdır. Sabit ya da tesadüfi etkiler modelinden hangisinin tercih edileceğine önsel olarak karar vermek mümkün olsa da bazı testler yardımıyla modellerin geçerliliği test edilebilmektedir. Tanımlama hatasını test etmek için geliştirilmiş Hausman (1978) spesifikasyon testi, panel veri modellerinde hangi tahmincinin seçilmesi gerektiği hususunda kullanılmaktadır (Yerdelen, 2016). Hausman testinin temel hipotezi bağımsız değişkenler ile birim ve zaman etkiler arasında korelasyon bulunmamaktadır biçimindedir. Böyle hallerde her iki tahminci de tutarlıdır ve tahminciler arasındaki fark oldukça küçüktür. Ancak tesadüfi etkiler tahmincisi daha etkin olduğundan bu tahmincinin kullanılması önerilmektedir. Tesadüfi etkiler tahmincisinin geçerli olduğunu ifade eden temel hipotez k serbestlik derecesi ve $\chi^{2}$ dağılım gösteren istatistik ile sınanmaktadır. Bu test istatistiği genelleştirilmiş en küçük kareler ve grup içi tahmincinin varyans kovaryans matrislerinin arasındaki fark kullanılarak hesaplanmaktadır. Hausman testi bu farkın sıfıra eşit olup olmama durumunu 
test etmektedir. Paremetreler arasındaki fark sistematikse sabit etkiler tahmincisi uygundur. Test istatistiği (2). eşitlikteki gibidir.

$\mathrm{H}=\left(\hat{\beta}_{S E}-\hat{\beta}_{T E}\right)^{\prime}\left[\operatorname{Avar}\left(\hat{\beta}_{S E}\right)-\operatorname{Avar}\left(\hat{\beta}_{T E}\right)\right]^{-1}\left(\hat{\beta}_{S E}-\hat{\beta}_{T E}\right)$

$\hat{\beta}_{S E}$ ve $\hat{\beta}_{T E}$ 'deki parametre sayısına göre $\chi^{2}$ dağılım göstermektedir.

Panel veri modelinin temel varsayımları; modelde değişen varyans (heteroskedasite), otokorelasyon ve birimler arası korelasyon bulunmadığı yönündedir. Modelde heteroskedasite, otokorelasyon ve birimler arası korelasyon bulunması durumunda hata teriminin varyans kovasyans matrisi birim matrise eşit olmamaktadır. Bu durum tahmin sonuçlarının tutarsız ve etkinliğinin düşük olmasına sebebiyet vermektedir. Temel varsayımdan sapmaların bulunduğu modelden elde edilen tahmincilerin standart hataları, $\mathrm{t}$ ve $\mathrm{F}$ istatistikler ile $\mathrm{R}^{2}$ ile güven aralıklarının geçerliliği önem arz etmektedir. Modelde heteroskedasite, otokorelasyon ve birimler arası korelasyondan en az birisi varsa dirençli standart hatalar ile elde edilecek tahmincilerin tahmin sonuçlarına güvenilmelidir. Sabit etkiler modelinde kalıntılardaki birimlere göre değişen varyans sınaması için normal dağılım varsayımı gerektirmeyen değiştirilmiş Wald testi (Greene, 2000) kullanılmıştır. Wald testi istatistiği, $\mathrm{W}=\sum_{i=1}^{N} \frac{\left(\sigma_{i}^{2}-\sigma^{2}\right)^{2}}{V_{i}}$ biçimindedir. $\sigma_{i}^{2}$, i. birimin kalıntı varyansının tahmincisi olmak üzere $\mathrm{W}$ test istatistiği $\mathrm{N}$ serbestlik derecesi ile $\chi^{2}$ dağılıma uymaktadır. Test sonucunda birimlere göre heteroskedasite olduğu ve varyansın birimlere göre değiştiği gözlemlenmiştir. Sabit etkiler modelindeki otokorelasyon, Bhargava, Franzini ve Narendranathan'ın DurbinWatson ve Baltagi-Wu'nun yerel en iyi değişmez testleri ile sınanmıştır. Modelde otokorelasyon olup olmadığını değerlendirmek açısından literatürde belirli bir kritik değer belirtilmezken, ortak görüş Durbin-Watson ve Baltagi-Wu LBI testlerinin 2'ye yakın ve 2 'den büyük değerler olduğunda sabit etkiler modelinde otokorelasyonun önemli kabul edilmeyeceği yönündedir. Birimler arası korelasyonun testi Friedman (1937) tarafindan geliştirilen test ile sınanmıştır. Spearman'ın rank korelasyon katsayısından hesaplanan ve parametrik olmayan bu test istatistiği (T-1) serbestlik derecesi ile asimptotik $\chi^{2}$ dağılmaktadır. $\mathrm{R}_{\mathrm{AV} \text { E }}$ ortalama Spearman korelasyonu katsayısını ifade etmek üzere (büyük değerleri sıfır olmayan birimler arası korelasyonu göstermektedir) Friedman (1937) test istatistiği $\mathrm{FR}=\left[(\mathrm{T}-1)(\mathrm{N}-1) \mathrm{R}_{\mathrm{AV} \text { E }}+1\right]$ şeklindedir. Test sonucunda panel veri modelinde birimler arasında korelasyon bulunduğu sonucuna ulaşılmıştır. Heteroskedasite, otokorelasyon veya birimler arası korelasyon gibi temel varsayımlardan en az birinin bulunduğu hallerde varsayımdan sapmalara uygun bir düzeltme metodunun seçilmesi önerilmektedir (Yerdelen, 2016, s: 87). Driscoll-Kraay tahmincisi N>T olduğu hallerde güçlü bir tahminci özelliği sergilemektedir. Ayrıca sabit etkiler tahmincisinin kullanıldığı modeller de tercih edilen bu tahminci heteroskedasite, otokorelasyon ve birimler arası korelasyonun bulunduğu durumlarda tutarlı parametre tahminleri yapmaktadir. 


\section{Bulgular}

İhracattaki büyümenin istihdam büyümesi üzerindeki etkisini analiz etmek amacıyla kullanılan panel verinin doğru model spesifikasyonuna sahip olması önem arz etmektedir. Modelin birim ve zaman etkiler içerip içermediği ve klasik, sabit ya da tesadüfi etkiler tahmincilerinden hangisi ile tahmin edileceğinin saptanması gerekmektedir.

Tablo 4'de uygun modelin seçimi için yapılan test sonuçları gösterilmektedir, birim ve zaman etkilerinin iki yönlü modelin geçerliliğini sınamak üzere yapılan en çok olabilirlik (LR) testi ile sınanmıştır. Birim ve zaman etkilerinin standart hatalarının en az birisinin sıfıra eşit olduğu $\mathrm{H}_{0}$ hipotezi reddedilememekte ve iki yönlü modelin geçerli olmadığ anlaşılmaktadır. F testi sonucunda sabit zaman etkiler modelinin klasik modele tercih edildiği; LR testi sonucunda ise rassal zaman etki modelinin klasik modele tercih edildiği görülmektedir. Hausman testi ile sabit yahut tesadüfi etkiler tahmincilerinin (1). eşitlikteki model için uygunluğu test edilmiştir. Hausman testi T'nin büyük N'in küçük olduğu durumlarda gücü düşük olmasına karşılık; küçük T ve büyük $N$ olduğu durumlarda sıkça kullanılmaktadır. Hausman test sonuçlarına göre $\mathrm{H}_{0}$ hipotezi reddedildiğinden, tesadüfi etkiler tahmincisinin tutarsız ve tek yönlü sabit zaman etkiler modelinin geçerli olduğu sonucuna ulaşılmıştır.

Tablo 4: Model Spesifikasyon Testi

\begin{tabular}{lcc}
\hline F Testi & LR Testi & Hausman Testi \\
\hline $\mathrm{F}_{\text {birim }}=1.19$ & $\mathrm{LR}_{\text {birim }}=0.01$ & $36.73^{*}$ \\
$\mathrm{~F}_{\text {zaman }}=3.38^{*}$ & $\mathrm{LR}_{\text {zaman }}=2.78^{* *}$ & \\
& $\mathrm{LR}_{\text {birim/zaman }}=2.78$ & \\
\hline
\end{tabular}

*\%1 anlam düzeyini, $* * \% 5$ anlamll1ık düzeyini ifade etmektedir.

Çalışmanın yöntem bölümünde belirtildiği üzere, temel varsayımlardan en az birinin bulunduğu hallerde hata terimlerine ait varyans-kovaryans matrisi birim matris olma niteliğini yitirmektedir ve tahmin sonuçlarının tutarsız ve etkinliğinin düşük olmasına yol açmaktadır. Bu nedenle modeldeki temel varsayımların test edilmesi gerekmektedir.

Tablo 5: Sabit Etkiler Tahmincisine Dayalı Panel Veri Modelinin Temel Varsayımlarının Testleri

\begin{tabular}{ll}
\hline Heteroskedasite & \\
\hline Değiştirilmiş Wald Testi & $18570.46^{*}$ \\
Otokorelasyon & \\
Durbin-Watson testi & 1.9612842 \\
Baltagi-Wu LBI & 1.9878024 \\
Birimler arası korelasyon & \\
Friedman Testi & 32.465 \\
\hline
\end{tabular}

Not: * prob $<0.05$ 
Sabit etkiler modelinde kalıntılardaki birimlere göre değişen varyans Greene (2000) tarafından önerilen $\chi^{2}$ dağılıma uyan değiştirilmiş Wald testi ile sınanmıştır. Test sonucunda birimlere göre değişen varyans olmadığını ifade eden $\mathrm{H}_{0}$ hipotezi reddedilmiştir. Daha açık bir ifadeyle, birimlere göre heteroskedasite vardır ve varyans birimlere göre değişmektedir. Otokorelasyon test sonuçlarına baktığımızda, sonuçları değerlendirmek açısından literatürde belirli bir kritik değer belirtilmemesine karşılık, ortak kanı Durbin-Watson ve Baltagi-Wu LBI testlerinin 2'ye yakın ve 2'den büyük değerler olduğunda sabit etkiler modelinde otokorelasyonun ciddi bir problem oluşturmadığı yönündedir. Burada hesaplanan test sonuçları 2'ye çok yakın değerlerdir. Birimler arası korelasyonun varlığı Friedman (1937) tarafından geliştirilen test ile sınanmıştır. Buna göre birimler arasında korelasyonun bulunmadığını ifade eden $\mathrm{H}_{0}$ hipotezi reddedilememiştir.

Tablo 6: Sabit Etkiler Tahmincisi (Driscoll-Kraay Standart Hatalar)

\begin{tabular}{lccc}
\hline Değişkenler & Katsayılar & Standart hatalar & t-istatistikleri \\
\hline $\ln \Delta$ istihdam $_{\text {it-1 }}$ & $0.235^{* *}$ & 0.107 & 2.19 \\
$\ln \Delta$ ihracat $_{\text {it }}$ & $-0.048^{* *}$ & 0.019 & -2.53 \\
$\ln \Delta$ emekmaliyet $_{\text {it }}$ & 0.002 & 0.014 & 0.020 \\
$\ln \Delta$ GSYİH $_{\text {it }}$ & $0.495^{* * *}$ & 0.140 & 3.53 \\
$\ln \Delta$ işsizliködemesi $_{\text {it }}$ & 0.051 & 0.036 & 1.39 \\
$\ln \Delta$ ticariaçıklık $^{\ln \Delta \text { finansalaçıklık }}$ & $0.101^{* * *}$ & 0.028 & 3.56 \\
Sabit Terim & -0.0002 & 0.0008 & -0.28 \\
$\mathrm{R}^{2}$ & 0.001 & 0.001 & 1.02 \\
\hline
\end{tabular}

Not: * \%1 anlam düzeyinde, $* * \% 5$ anlam düzeyinde, $* * * \% 10$ anlam düzeyinde

Panel veri modelinde heteroskedasite, otokorelasyon veya birimler arası korelasyon gibi temel varsayımlardan en az birisi bulunuyorsa hata terimlerine ait varyans-kovaryans matrisi birim matris olma niteliğini yitirmektedir. Böyle hallerde varsayımdan sapmalara uygun bir düzeltme metodunun seçilmesi önerilmektedir (Yerdelen, 2016, s. 87). Driscoll-Kraay tahmincisi N>T olduğunda güçlü bir tahminci özelliği sergilemektedir. Ayrıca sabit etkiler tahmincisinin kullanıldığ 1 modellerde tercih edilen bu tahminci heteroskedasite, otokorelasyon ve birimler arası korelasyonun bulunduğu durumlarda tutarlı parametre tahminleri yapmaktadır. Tablo 6, Driscoll-Kraay tahmincisi dirençli standart hatalar ve t istatistikleri ile katsayı tahmin sonuçları verilmiştir. Buna göre, ihracattaki büyümenin \%1 artışı istihdamdaki büyümeyi \%0.04 oranında azaltmaktadır. Bir dönem önceki istihdam büyümesindeki \%1'lik artış istihdam büyümesini \%0.23 oranında artırmaktadır. İstihdamın bir dönem önceki seviyesinin istihdamdaki değişimi pozitif yönde etkilemekte anlamlı olduğu görülmektedir. GSYİH'deki büyümenin \%1'lik artışı istihdamdaki büyümeyi \%0.49 oranında artırmaktadır. Ticari açıklık büyümesinin \%1 artması istihdamdaki büyümeyi \%0.10 oranında artırmaktadır. İşsizlik ödemesi, finansal açıklık ve emek maliyetlerindeki büyümenin istihdamdaki büyüme üzerindeki etkisi anlamsız bulunmuştur. 
İhracattaki büyümenin istihdamdaki büyüme üzerindeki etkisini analiz eden panel veri modeli, sabit etkiler tahmin tekniklerinden yararlanılarak oluşturulmuştur. Modelin temel bağımsız değişkeni ihracattaki büyüme iken; ekonomik büyüme, birim emek başına maliyetler, ticari açıklık, finansal açıklık ve işsizlik ödemesi oranlarındaki büyüme istihdam büyümesini etkileyen diğer bağımsız değişkenler olarak modelde yer almaktadır. Çalışmanın bulgularına göre; teorik ve önsel beklentilerimize uygun olarak; bir önceki dönemdeki istihdam artış ya da azalışı, cari dönemdeki istihdam artış ya da azalışını açıklamakta anlamlıdır. Önceki dönemdeki istihdam büyümesinin \%1 oranında artışı ya da azalışı cari dönemdeki istihdam büyümesini \%0.23 oranında ve aynı yönde etkilemektedir. İhracattaki büyümeler istihdamda yaşanan büyümeyi açıklamakta anlamlıdır. Ancak ihracattaki bir değişim istihdamdaki değişimi negatif yönde etkilemektedir. İhracattaki büyüme \%1 arttığında istihdamdaki büyüme \%0.04 oranında azalmaktadır. Elde edilen bu bulgu geleneksek ticaret teorileri ve onlar temelinde gerçekleştirilmiş ampirik uygulamalı bir çok çalışmanın ortaya koyduğu sonucun aksini iddia etmektedir. Fakat son dönemde yapılan birçok çalışmada ihracat ile istihdam arasında anlamlı ilişki bulunamadığı gibi ihracatın istihdamı negatif etkilediği çalışmalar da yer almaktadır. Çalışmamız sonucunda elde ettiğimiz, ihracat değişimlerinin istihdamdaki değişimi negatif yönde etkilediği sonucu Greenway (1991), Jenkins (2004), Were (2011), Aktakaş ve ark. (2013) ve Ko ve ark. (2015) tarafından elde edilmiş tahmin sonuçlarıyla paralellik göstermektedir. Modelde yer alan diğer bağımsız değişkenlerden olan ekonomik büyüme, ticari açıklık oranındaki büyüme istihdam büyümesini açıklamakta pozitif yönde anlamlıdır. Modelden elde ettiğimiz tahminlerde birim başı emek maliyetlerindeki ve işsizlik ödemesi oranlarındaki büyüme istihdamdaki büyümeyi açıklamakta anlamlı değildir. İstihdamdaki büyümeyi açıklayan değişkenler arasında katsayı itibari ile en fazla etkileyen değişken ekonomik büyümedir.

\section{Sonuç}

Dış ticarette serbestleşme sonrasında ülkelerin ihracatın istihdam üzerinde olumlu etkiler doğurduğu geleneksel ticaret teorileri temelinde tartışılmaya başlanmıştır. Bu tartışmalar çoğunlukla ihracat artışlarının ekonomik büyümeyi desteklediği ve bunun istihdamdaki artışı tetikleyeceği yönündeki mekanizmaya dayandırılmaktadır. Yeni ticaret teorilerinin başkalaşan varsayımlarına dayalı olarak endüstriyel ve firma düzeyinde gerçekleştirilen araştırmalar da ihracatın istihdamı desteklediğini doğrulamak üzere yapılmış incelemelerden oluşmaktadır. Ancak kısa vadede istihdam yaratan ihracata dönük sektörler uzun dönemde üretim yapılanması ve teknolojik değişime bağlı olarak vasıflı emek taleplerini artırırken, vasıfsız emeğin talebindeki azalmaya bağlı olarak ihracat artışlarının istihdam yaratıcı etkisi daha çok sorgulanır hale gelmiştir. Bu çalışmadan elde edilen bulgular 28 OECD ülkesinin 2001-2019 yıllarında ihracat büyümesinin istihdam büyümesini negatif yönde etkilediğini ortaya koymaktadır. Ampirik analiz sonucunda elde edilen tahmin sonuçları, çalışmanın 
giriş bölümünde belirlenmiş olan temel hipotezin reddedildiği manasına gelmektedir. Temel teorik beklentiler bu ilişkinin aksini ortaya koyma eğiliminde olmaktaysa da, dünyadaki güncel gelişmeler ihracat artışlarının istihdam üzerindeki olumlu etkinin ülkelerin ekonomi politikaları başta olmak üzere kurumsal yapısı, istihdam politikaları ve eğitim politikaları gibi birçok faktörle beraber hareket ettiğini göstermektedir. Dış ticaretin serbestleşmesiyle kaynak kullanımında etkinliğin sağlanması ve üretimde uzmanlaşma ile ülkeler hızla istihdam ve GSYİH'lerini artırmıştır. Ancak uluslararası rekabet ve üretim aşamasında teknolojiye daha bağlı üretim biçimi tüm sektörlerin talep ettiği emek biçimini değiştirmiştir. Sanayileşme aşamasında olan gelişmekte olan birçok ülkede ihracat artışları vasıfsız emek için istihdam alanı oluştururken, sanayileşmesini tamamlamış, istihdamda hizmetler sektörünün payı hızla artmış olan ülkelerdeki çoğu sektör vasıflı emek talebini artırmıştır. Diğer taraftan, önceleri emek yoğun üretim biçimi ile üretilen çoğu mal, teknolojinin sunduğu üretim biçimlerinden faydalanarak emek talebinin düşmesine ve istihdamda azalmaya neden olmuştur. Nitekim çoğu uluslararası birlik ve kuruluş, ülkelerin yaşadığı ekonomik büyümenin ülkelerin ihtiyaç duyduğu istihdamı gerçekleştirmediğini ifade eden "işsiz büyüme” olgusunu tartışma gündemlerinde tutmaktadır.

Çalışma dünyasında değişimin hızlandığı bu çağda hem işçiler hem de işverenler için işgücü piyasasının gerekli kıldığı beceri ve nitelikleri sağlayabilmesi amacıyla gerekli sistemlerin güçlendirilmesi önem arz etmektedir. Hızla değişen piyasa talebine adaptasyonun sağlanması ve uyumu teşvik edebilecek rekabetçi bir ortamın yaratılması kritik öneme sahiptir. Politika yapıcılar ve sosyal ortaklar, eğitim ve öğretim sistemlerini endüstriye bağlama ve emek arzını taleple eşleştirme konusundaki aktif işbirliği yoluyla bu bağlamda oynayacakları kilit bir role sahiptir.

Bu çalışma OECD üyesi ülkeler özelinde ihracat artışlarının istihdam üzerindeki etkisini makro ölçekte ve panel veri tekniklerinden yararlanarak analiz etmiştir. Ancak güncel ekonomik tartışmalar, ihracatın istihdam üzerindeki dolaylı etkilerini hizmetler sektörü itibariyle kendisini ortaya çıkardığı hipotezini sorgulama eğilimindedir. Buna dayalı olarak, bu çalışmanın tamamlanmasıyla şekillenen yeni çalışma sorusu dış ticaretin, ihracatın ve ithalatın hizmetler sektöründeki istihdama etkisinin ne olduğudur. Bununla beraber, 2020 yılının birinci çeyreğinden itibaren tüm dünyayı etkisi altına alan ve devam eden Covid-19 Salgınının ekonomik etkileri, tüm dünya ülkelerince kabul edilen tartışma götürmez bir gerçektir. Covid-19 Salgınının işgücü piyasalarında oluşturduğu şok etki işsizlik, yeni çalışma biçimleri, ücret düzenlemeleri gibi pek çok başlıkta dönüşüme işaret etmektedir. $\mathrm{Bu}$ bilgiler yelpazesinde alana kazandırılacak yeni çalışmalarda bu dönüşümün de göz önünde bulundurularak analizlerin yapılması, ihracat ve istihdam ilişkisini farklı bir boyutta tartışma imkanı sunacaktır. 
Hakem Değerlendirmesi: Dış bağımsız.

Çıkar Çatışması: Yazar çıkar çatışması bildirmemiştir.

Finansal Destek: Yazar bu çalışma için finansal destek almadığını beyan etmiş̧ir.

Peer-review: Externally peer-reviewed.

Conflict of Interest: The author has no conflict of interest to declare.

Grant Support: The author declared that this study has received no financial support.

\section{Kaynakça/References}

Akcoraoglu, A., \& Senay, A. (2011). Employment, international trade and foreign direct investment: Time series evidence from Turkey. International Research Journal of Finance and Economics, 76, 89-101.

Akkuş, G. E. (2014). The effects of trade and productivity on employment in the manufacturing industry of Turkey", Iktisat Fakültesi Mecmuast, 64(2), 1-44.

Aktakaş, B. G., Mike, F., Aytun, C., \& Laleh, M. M. (2013). The relationship of sectoral export-employment: the case of Turkey (2004-2011), Journal of Cukurova University Faculty of Economics and Administrative Sciences, 17(1), 37-50.

Aswicahyono, H., Brooks, D. H., \& Manning, C. (2011). Exports and Employment in Indonesia: The Decline in Labor-Intensive Manufacturing and the Rise of Services. Asia Development Bank Economics Working Paper Series No. 279.

Baltagi, B. H. (2005), Econometric Analysis of Panel Data, (3.bs), England John Wiley \& Sons,Ltd.

Bernard, A. B., \& Jensen, J. B. (1997). Exporters, skill upgrading, and the wage gap. Journal of International Economics, 42, 3-31.

Bernard, A. B., Jensen, J. B., Redding, S. J., \& Schott, P. K. (2007). Firms in international trade. The Journal of Economic Perspectives, 21(3), 105-130.

Dizaji, M., \& Badri, A. K. (2014). The effect of exports on employment in Iran's economy. Merit Research Journal of Art, Social Science and Humanities, 2(6), 81-88, Erişim adresi: http://www.meritresearchjournals.org/assh/ index.htm

Edwards, L. (2004). A firm level analysis of trade, technology and employment in South Africa, Journal of International Development, 16, 45-61.

Erlat, G. (2000), Measuring the impact of trade flows on employment in the Turkish manufacturing industry, Applied Economics, 32(9), 1169-1180.

Feenstra, R. C., \& Hong, C. (2007). China s’ Exports and Employment NBER Working Paper 13552, Erişim adresi: http://www.nber.org/papers/w13552.

Friedman, M. (1937). The use of ranks to avoid the assumption of normality implicit in the analysis of variance, Journal of the American Statistical Association, 32, 675-70.

Fu, X., \& Balasubramanyam, V. N. (2005). Exports, Foreign Direct Investment and Employment: the Case of China. Blackwell Publishing Ltd 2005.

Ghani, E. (2010). The Service Revolution in India. VOX CEPR's Policy Portal, Erişim adresi: https://voxeu.org/ article/services-led-growth-india-new-hope-development-late-comers

Greene, W. H. (2000). Econometric Analysis, 5.ed, Prentice Hall, Upper Saddle River, New Jersey, Retrieved from https://spu.fem.uniag.sk/cvicenia/ksov/obtulovic/Mana\%C5\%BE.\%20\%C5\%A1tatistika\%20a\%20 ekonometria/EconometricsGREENE.pdf

Greenway, D., Robert, C. H., \& Wright, P. (1999). An empirical assessment of the impact of trade on employment in the united kingdom. European Journal of Political Economy, 15(3), 485-500. 
Gül, E., \& Kamac1, A. (2012). Effects of international trade on employment: A panel data analysis, Anadolu University Journal of Social Sciences, 12(4), 23-32.

Hausman, J. A. (1978). Specification tests in econometrics, Econometrica, 46(6), 1251-1272.

Heckscher, Eli F. (1949). The effect of foreign trade on the distribution of income, N:21, 1919, 497-512, translated in American Economic Association, Readings in the Theory of International Trade (Philadelphia: Blakiston), $272-300$.

Hoekman, B (2006). Liberalizing Trade in Services: A Survey. World Bank and CEPR, WB Policy Research, Working Paper, WPS4030.

Hoekman, B., \& Winters, L. A. (2005). Trade and Employment: Stylized Facts and Research Findings, DESA Working Paper No.7, ST/ESA/2005/DWP/7

Hsiao, C. (2003). Analysis of Panel Data, (2.bs), UK, Cambridge Universty Press.

ILO, Jansen, M. ve Lee, E. (2007). Trade and Employment Challenges for Policy Research. WTO Secretariat, Switzerland.

ILO, Tarjáni, H. (2017). Employment Implications of Trade and Changes in Skills Demand: Evidence from Selected Countries. Employment Policy Department, Employment Working Paper No. 237.

ILO, (2018). Spotting Export Potential and Implications for Employment in Developing Countries, Strengthen Publication Series, Working Paper No. 5

Jenkins, (2004). Vietnam in the global economy: trade, employment and poverty. Wiley, 16(1), 13-28.

Karaçor, Z., \& Saraç, T. B. (2011). Dış ticaret ile sanayi sektörü istihdam oranı arasındaki kısa ve uzun dönem ilişkisi: Türkiye örneği (1963-2009). Yönetim ve Ekonomi, 18(2), 181-194.

Khan, A. H. (1991). Employment creation effects of Pakistan's exports. The Pakistan Development Review, 30(4), $865-877$.

Kılınç Savrul, B., \& Kaynak M. (2020). Sektörel ihracatın istihdam üzerindeki etkisi: Türkiye için panel veri analizi. Eurasian Academy of Sciences Social Sciences Journal, 31, 30 - 62.

Kiyota, K. (2014). Exports and Employment in China, Indonesia, Japan and Korea. OECD Trade Policy Papers, No: 166, 1-25. Retrieved from http://dx.doi.org/10.1787/5jxzqqw84vmp-en

Ko, K., Rangkakulnuwat, P., \& Paweenawat, S. (2015). The effect of international trade on labor demand in ASEAN5. Economics Bulletin, 35(2), 1034-104.

Konan, D., \& Maskus, K. (2006). Quantifying the impact of services liberalization in a developing country. Journal of Development Economics, 81, 142-162.

Krugman, P. (1979). Increasing returns, monopolistic competition and international trade. Journal of International Economics, 9(4), 469-479.

McMillan, M., \& Verduzco, I. (2011). New evidence on trade and employment: an overview. In Jansen, M., Peters, R., Salasar-Xirinachs, J., eds. Trade and employment: from myths to facts, International Labour Office, Geneva.

Melitz, M.J. (2003). The impact of trade on intra-industry reallocations and aggregate industry productivity. Econometrica, 71(6), 1695-1725.

Muratoğlu, Y. (2011). Büyüme ve istihdam arasındaki ilişki: Türkiye örneği, Conference: International Conference on Eurasıan Economies. Erişim adresi: https://www.avekon.org/papers/335.pdf

Myint, H. (1958). The "Classical Theory" of international trade and the underdeveloped countries, The Economic Journal, 68(270), 317-337.

Nguyen, T. K. (2015). Manufacturing exports and employment generation in Vietnam. Southeast Asian Journal of Economics, 3(2), 1-21. 
Nurkse, R. (1961), Patterns of trade and development, Wicksell Lectures (Oxford: Basil Blackwell).

OECD (2007). Employment Outlook. Retrieved from https://doi.org/10.1787/19991266

Polat, Ö., \& Uslu, E. E. (2011), "Impact of international trade on employment in manufacturing industry of Turkey", African Journal of Business Management, 5(13), 5127-5135.

Polat, Ö., Uslu, E. E., \& Aydemir, C. (2011), Analysis of trade and employment in manufacturing industry using panel data method, Business and Economics Research Journal, 2(3), 161-171.

Rima, I. H. (2004). China's trade reform: Verdoorn's law married to Adam Smith's "Vent for Surplus" principle', Journal of Post Keynesian Economics, 26(4), 729-44.

Stolper, W. F., \& Samuelson, P. A. (1941). Protection and real wages. The Review of Economic Studies, 9(1), 58-73.

Tandoğan, D. (2019). The impact of export on employment: panel data analysis for regional base in Turkey. Bingöl Üniversitesi Sosyal Bilimler Enstitüsü Dergisi, 9(18), 799-814.

UNCTAD, (2018). Trade in Services and Employment. United Nations Conference on Trade and Development. Retrieved from https://unctad.org/system/files/official

Were, M. (2011). Is there a link between casual employment and export-orientation of firms? the case of Kenya's manufacturing sector, Rev Black Polit Econ, 38, 227-242, doi 10.1007/s12114-011-9099-x

Yerdelen Tatoğlu, F. (2016). Panel Veri Ekonometrisi, 3.bs, Beta, İstanbul. 
